\title{
Echo i medium
}

Jakub Momro

TEKSTY DRUGIE 2016, NR 2, S. 38-54

DOI: $10.18318 /$ td.2016.2.3

A zatem gtos nie zostaje przyswojony, lecz wchtonięty. Oto, co może mu nadawać funkcję formowania naszej pustki.

Jacques Lacan

Ale syreny maja jeszcze straszniejszą broń od śpiewu, a mianowicie milczenie.

Franz Kafka

Nie sytuuje się to nigdzie, ani $w$ naturze, ani $w$ kulturze, ale zaznacza się $w$ przestrzeni podwojenia, echa i rezonansu, w którym to nie ktoś, lecz ta nieznana przestrzeń - jej rozstrojony akord, jejwibracja-mówi bez stów.

Maurice Blanchot

Dźwięk może być przeto równie dobrze tylko litera, ponieważ element styszalny, podobnie jak widzialny redukuje się do tego, by byćli tylko aluzją do ducha.

Georg Wilhelm Friedrich Hegel

\section{Jakub Momro -}

adiunkt w Katedrze Antropologii Literatury i Badań Kulturowych na Wydziale Polonistyki UJ, filozof, literaturoznawca i tłumacz tekstów teoretycznych. Opublikował książki: Literatura świadomości.Samuel Beckett-podmiot negatywność (2010), Widmontologie nowoczesności. Genezy (2014). Członek redakcji „,Tekstów Drugich" oraz współredaktor serii wydawniczej "Nowa Humanistyka". Kontakt: jakub. momro@wp.pl

11 jednym z tekstów składających się na tom Leçons 
Właściwy zapis [muzyki] może samodzielnie wytwarzać [...] nieustanną plastyczność i ciągłość: uruchamia grę między rzeczywistością a iluzją; pochwytujemy przedmiot, lecz nie jesteśmy pewni, czy aby nie schwyciliśmy fantazmatu. W zdarzeniu muzycznym zawsze powinna istnieć sieć perspektyw, które prowadziłyby nas od jednego do drugiego przedmiotu coraz bardziej oddalonego od źródła, aby doprowadzić do zarazem logicznych, jak i nieprzewidywalnych wniosków. Chodzi o sytuację podobną do tej, z jaką mamy do czynienia w niektórych opowiadaniach Kafki. Z tego punktu widzenia najbardziej fascynujący jest, jak sądzę, zwłaszcza $W y$ rok. Absolutna pewność dzieła kieruje się w stronę niepewności chwili i w niej samej się potwierdza: między porządkiem a chaosem istnieje miejsce dla bardziej niestabilnej, ulotnej i bogatszej sfery wyobraźni jako percepcji. ${ }^{1}$

Boulez nie mówi tu o muzyce samej w sobie, choć pierwsze zdanie z przytoczonej wypowiedzi mogłoby na to wskazywać. Chodzi mu raczej o to, by pokazać, w jaki sposób można myśleć o medium dźwiękowym jako o czymś więcej niż tylko asemantycznym nośniku brzmienia. Francuski kompozytor zastanawia się bowiem nad statusem nowoczesnej ontologii zapośredniczenia, którego sfera dźwiękowa jest swego rodzaju wcieleniem. To właśnie dlatego nie tylko muzyka, ale również cała fonosfera stają się tak ważne, kiedy chcemy myśleć o tym, co jest filtrem, przez który przepuszczamy nasze doświadczenia i doznania, pojęcia i fantazmaty. Wibrujący dźwięk wydaje się doskonałą figurą niepewności związanej z elementarną sytuacją podmiotu, który słucha, słyszy i nasłuchuje. Ale nie ten aspekt dźwięku będzie mnie tu interesował. Bardziej niż formy, jakie przybiera subiektywność, interesuje mnie związek między dźwiękową mediatyzacją i jej wymiarem materialnym.

Jak rozumieć tę relację między medium i akustyczną inkorporacją? Dźwięk jako obiekt należałoby tu rozumieć jako miejsce, w którym dochodzi do samozniesienia medium; wybrzmiewając, a więc trwając w czasie, dźwięk istnieje, rzecz jasna, jako suma momentów, lecz istotniejszy jest w tym przypadku właśnie ów samozwrotny ruch ustanawiania i negowania obecności, jej uwypuklenia i neutralizacji, jej mocy i wygaszania. Co więc je st dźwiękiem? Dźwięk to obiekt rozumiany jako pewna przestrzeń sensualności czy sensoryczności, sfera, której nie wypełniają jednak wyłącznie postrzeżenia,

1 P. Boulez Leçons de musique. Points de repère III, Christian Bourgois, Paris 2005, s. 467 [przekł. autora]. 
ale przede wszystkim możliwość wiedzy o świecie. Epistemologia, ukonstytuowana na dźwięku jako paradygmacie medium nowoczesnego, pozwala zrozumieć, w jaki sposób zasada reprezentacji zostaje zastąpiona regułą relacji. Przedstawienie, utrzymujące podział na podmiot i przedmiot, przestaje funkcjonować jako idea regulatywna, w jej miejsce pojawia się właśnie dynamiczna, zmienna i plastyczna ${ }^{2}$ relacja między przedmiotami oraz między przedmiotami i podmiotem. Dźwięk zatem nie stanowi jedynie przedmiotu zmysłowego doświadczenia, lecz raczej działa na zasadzie otwarcia pewnej możliwości poznawczej w tym znaczeniu, że umożliwia poznanie poprzez sensualną formę, która sama staje się treścią. O niczym innym nie mówi Boulez: słuchanie, które jest również pochwytywaniem i ujmowaniem świata zewnętrznego wobec podmiotu, prowadzi do zamazania różnicy między rzeczywistością a jej słabszym bądź mocniejszym odbiciem, echem, a więc ostatecznie - akustycznym widmem. Dźwięk sam siebie znosi, co oznacza tyle, że trwając, będąc rozciągłym w czasie i ujawniając własną materialność, równocześnie ją neutralizuje - jego istnienie jest podminowane nieobecnością, a nawet więcej: nieobecność jest warunkiem możliwości jego istnienia. Tak oto wymiar poznawczy dźwięku, a więc nie tyle gotowa do odkrycia sensualna treść czy abstrakcyjna forma, ile samonapędzający się mechanizm rozpoznawania zasady rzeczywistości (dźwięk wskazuje, niemal na zasadzie odwróconej deiksy, na to, co istniejąc, zarazem wymazuje własne istnienie, a więc na konstytutywną pustkę) spotyka się z wymiarem ontologicznym (status bytowy dźwięku jest warunkowany przez własną niemożliwość, a zatem jego obecność zawiera w sobie własną negację).

Taki rodzaj poznania poprzez dźwięk prowadzi, jak podpowiada Boulez, do nierozstrzygalności, która tyleż blokuje, co ustanawia zdarzenie jako takie. Jego kondensacja w postaci dźwiękowej to z kolei nic innego jak określone w każdej chwili i nieustannie zmieniające się pole immanencji³. Samą immanencję należy tu rozumieć jako rodzaj miejsca (dla) osobliwości - tego, co niepowtarzalne i wyjątkowe, jednorazowe i pojedyncze. Czyż dźwięk nie jest właśnie tak rozumianą osobliwością? Można powiedzieć, że stanowi on zaprzeczenie źródłowości: rozlegając się w powietrzu i tworząc akustyczną przestrzeń zmysłowości, zarazem odsyła do tego, co już nie istnieje,

2 Por. fundamentalne studium: C. Malabou L'avenir de Hegel. Plasticité, temporalité, dialectique, Vrin, Paris 1996, oraz tejże Plasticité au soir de l'érciture. Dialectique, destruction, déconstruction, Léo Scheer, Paris 2005.

3 Por. G. Deleuze L'immanence: une vie..., w: tegoż Deux régimes de fou, Minuit, Paris 2003. 
a wyznacza miejsce dla tego, czego jeszcze nie ma. Innymi słowy, jeśli dźwięk stanowi osobliwość, to jest nią na zasadzie stawania się, a nie reprezentacji, okazuje się reperkusją tego, co pozbawione początku, akustyczną multiplikacją ${ }^{4}$, zjawiskiem bez końca odsyłającym do siebie i wymazującym to odniesienie. Przekreślone źródło uzmysławia, że przestrzeń dźwięku, jego ontologia i wpisana w nią epistemologia, to sfera zmysłowości, którą można określić mianem materializmu bez medium. Zapośredniczenie stanowi więc nie tyle nośnik znaczenia czy semiotyczną przesłonę, ile raczej własną negację. W ten sposób mediacja dźwiękowa jest ruchem od tego, co oddziałuje bezpośrednio (jako siła sensoryczna), do tego, co staje się odciętym od źródła5, autonomizującym się, ale i eliptycznym zjawiskiem brzmieniowym.

Echo jako widmo dokonuje, by tak rzec, samokorekty, retrakcji ${ }^{6}$; zostaje skrócone ${ }^{7}$, tzn. pozbawione semantycznej i semiotycznej nośności. Echo jako widmo nie jest więc znakiem, lecz miejscem zneutralizowanego zapośredniczenia, sferą podziału immanencji: brzmienie echa to nic innego jak odbity dźwięk czy nawet głos poza zasadą podmiotowości. Z tej perspektywy nie jest bowiem istotne, kto mówi i kogo obrazuje akustyczna reprezentacja, lecz to, w jaki sposób dźwięk autonomizuje się w czasie, który został mu dany. Na istnienie dźwięku składają się rozmaite modalności czasu, których wszelako nie sposób od siebie oddzielić: teraźniejszość niejako skupia w sobie przeszłość i antycypację, potencjalność i aktualność. Toteż zdarzenie należałoby tu rozumieć jako modalność czasu teraźniejszego, a nawet więcej: teraźniejszości stającej się rozziewem w obrębie tego, co obecne, ontologiczną luką, która tyleż tworzy porządek rzeczywistości, co go unieważnia - dźwiękowa ontologia jest więc ufundowana na braku, ujawniającym się w chwili, w momentalnym zjawisku akustycznym. To właśnie wtedy, gdy rozpoznajemy w nim właściwą mu czasowość, czy raczej: gdy ujawnia się sama możliwość temporalności dźwięku, do głosu dochodzi jego widmowy charakter. Aporia polegająca na

4 Por. P. Lacoue-Labarthe Echo podmiotu, przeł. J. Momro, w: tegoż Typografie, przeł. J. Momro, A. Zawadzki, wstęp, oprac., red. J. Momro, Universitas, Kraków 2014.

5 Por. J.-L. Nancy Le discours de la syncope. Logodaedalus I, Aubier Flammarion, Paris 2008.

6 Te dwie cechy widma dobrze podsumowuje figura retoryczna zwana epanorthosis, polegająca nie tylko na "odsyłaniu do czegoś", ale również na substytucji tego, co zostało już powiedziane przez to, co - jako właściwsze - powinno się pojawić w miejscu tego pierwotnego wypowiedzenia.

7 Por. W. Hamacher Premises. Essays on Philosophy and Literature from Kant to Celan, trans. P. Fenves, Stanford University Press, Stanford 1999. (Esej tytułowy). 
współistnieniu różnych modalności czasu pozwala lepiej zrozumieć napięcie między empirią i pojęciem, zmysłowością i językiem. Ostatecznie bowiem akustyczny model ontologii wykracza poza te aporie właśnie dlatego, że jest wcieleniem nierozwiązywalnego paradoksu czasowości.

Nie oznacza to, że dźwięk da się opisać tylko w kategoriach negatywnych, jako to, co niewyrażalne. Jest dokładnie na odwrót: dźwięki, jak twierdzi Adorno ${ }^{8}$, stanowią język par excellence, jednak nie w znaczeniu mocy komunikacyjnej czy reprezentacyjnej, lecz jako obraz. Rzecz jasna, nie chodzi w tym wypadku o przedstawienie ani o odniesienie podmiotu do przedmiotu. Aby pomyśleć obraz niereprezentacyjny, należy potraktować aporię obecności-nieobecności w kategoriach, jak to słusznie określa Boulez, pewnej możliwości wyobraźni, która poprzedza percepcję, albo jeszcze inaczej: percepcji stającej się wyobraźnią. Tę relację między obrazem, antynomią obecności i czasu, postrzeganiem i wyobraźnią należy traktować w kategoriach krytycznych w ścisłym sensie. Innymi słowy, jeśli obraz leży u podstaw wszelkiej ontologii, to dzieje się tak dlatego, że stanowi on granicę zarówno form istnienia, jak i zasad poznawczych.

Ten krytyczny punkt wyjścia można rozumieć w sensie kantowskim. Jeśli zatem dźwięk w swej aktualizacji pełni funkcję graniczną, oddzielającą poznanie od otchłannej epistemologicznej niemożliwości, to dzieje się tak dlatego, że wyobraźnia jako taka, w ścisłym sensie transcendentalna, pozostaje pusta. Ruch w jej ramach jest, jak podpowiada trafnie Jean-Luc Nancy, dosłownie przemocą, sprowadzeniem wielorakości postrzeżeń i doznań do konkretnego miejsca w czasie i przestrzeni. Tak rozumiana wyobraźnia jest pewnego rodzaju schematyzacją świata opartego na sekretnej naturze absolutnej jedności, konstytuującej wszelkie poznanie. Innymi słowy, obraz jako taki nie jest zwykłą reprezentacją, lecz formą obecności, która nie ma żadnego ugruntowania. Nie sposób bowiem pójść dalej w redukcji bytu:

Ów czysty obraz to obraz obrazów, otwarcie jedności jako takiej. Gwałtownie zwija on rozczłonkowaną zewnętrzność, lecz jego fałda, owa ściśnięta fałda jest również szczeliną, którą jedność rozcina w zwartości powierzchni [étendue]. Czysty obraz jest trzęsieniem ziemi bytu, odsłaniającym uskok i brak w obecności. Tam, gdzie byt był w sobie, obecność nie powróci już do siebie: skutkiem tego byt jest lub będzie dla siebie.

8 Por. T.W. Adorno Quasi una fantasia. Essays on Modern Music, trans. R. Livingstone, Verso, London-New York 2011, s. 1-8. 
Można zrozumieć, w jaki sposób czas, pod wieloma względami, jest samą przemocą...9

Jak z tej perspektywy wyglądałby obraz akustyczny? Jeśli, jak mówi Nancy w swym komentarzu do Kanta i Heideggera, obraz rozszczelnia formę, w jakiej przejawia się istnienie, to można powiedzieć, że otwarcie immanencji umożliwia zarazem zbudowanie relacji między obiektami. Brzmienie i dźwięki są więc obrazami o tyle, o ile wskazują na własną czasowość, a co za tym idzie, względność i doraźny status. Czas, będący „samą przemocą”, to w tym wypadku nic innego jak rozziew w łonie bytu, a ontologia, która wyrasta z tej rozbieżności między istnieniem a nieistnieniem, zasadza się na nieustannej plastycznej metamorfozie związków, jakie między nimi się tworzą. Chodzi zatem o inny rodzaj czasowości, taki, który nie byłby już źródłem przemocy (nie byłby opresyjną jednorodnością wyobraźni), lecz warunkowałby możliwość powtórzenia. Czas obrazu akustycznego, czas w obrazie akustycznym to echo, które zaznacza swoje istnienie tylko przez nieciągłość i niepodobieństwo: potwierdza i różnicuje samo istnienie, staje się pojęciem i jego ucieleśnieniem, żyje i umiera w jednej chwili, której nie sposób pochwycić. Wynika stąd, że choć zasada relacyjności determinuje obraz akustyczny, to - ostatecznie - nie sposób o niej myśleć w kategoriach ontologicznych. Wydaje się bowiem, że opisowe kategorie „pęknięcia” czy „szczeliny”, jakich w ogólnym sensie używa Nancy, wciąż tkwią w dualistycznym języku, w którym każda forma życia zawiera mroczne tło w postaci rozmaitych figur negatywności. Tymczasem obiekt dźwiękowy, który wyrasta z obrazu akustycznego, całą swoją dwuznaczność, płynność i plastyczność ujawnia w innej niż ontologiczna formie czasowości. Dźwięku nie daje się pochwycić ani w system pojęć i języka, ani jako bytu, lecz w jego własnym zjawianiu się, własnej przechodniości. Dźwięk pozostaje medium w postaci obrazu (w znaczeniu przywołanym powyżej), który stanowi pewne pole możliwości: jest albo zapowiedzią, albo sygnałem czegoś innego, albo wreszcie: śladem własnej chwilowości, resztką wytrącającą się w postaci oddźwięków.

A jednak należałoby dokonać w tym miejscu niewielkiego, ale niezwykle znaczącego przesunięcia, tzn. nie tylko przejścia od ontologii do „innej” czasowości, lecz przede wszystkim od widma jako tego, co staje się nawiedzonym

9 J.-L. Nancy Image et violence, w: tegoż Au fond des images, Galilée, Paris 2003, s. 51. Nancy swoją analizę zawdzięcza oczywiście książce Heideggera poświęconej Kantowi. Por. M. Heidegger Kant a problem metafizyki, przeł. B. Baran, PWN, Warszawa 1989. 
duchem właśnie w procesie zjawiania się, by tak rzec, w rozwinięciu wizualizacji i ekspozycji, do echa, będącego figurą medium, które unieważnia własną materialność. Widmo wizualne jest więc tym, co powracając z przeszłości, rozbija egzystencjalną tożsamość i ontologiczną spójność świata, co zawsze, nawet (a może przede wszystkim) fragmentarycznie, pojawia się, tzn. staje się w ścisłym sensie fenomenem: obcym, wykluczonym, wypartym, niechcianym. Widmo akustyczne nie pozostawia śladów (w znaczeniu tropu empirycznego), rozsnuwa się w przestrzeni w postaci tego, co jeszcze nie jest w pełni obecne bądź już nie istnieje, między powstawaniem a ginięciem. W ten sposób jest ono granicą między ciągłością („Ucho nie ma powieki”, jak mówił Lacan) a nieciągłością dźwiękowej intensywności (Nigdy nie słyszymy wszystkiego).

W ten sposób, niczym w mitycznej opowieści, echo przestaje pełnić funkcję emblematu czy figury i przeobraża się w swoiste i paradoksalne odcieleśnione ciało, które realizując swe istnienie w rwanych, skąpych repetycjach, obrazuje rzeczywistość bez początku i końca, a ostatecznie - bez celu. Jeśli więc, jak mówił Boulez, w przypadku muzyki (a szerzej: fonosfery) wyobraźnia staje się percepcją, to nie należy tego przemieszczenia traktować w kategoriach zasadniczej zmiany paradygmatu doświadczenia. Nie chodzi tu bowiem o zastąpienie wzroku przez słuch, jednych zmysłów przez drugie, lecz o potraktowanie postrzegania jako płaszczyzny poznawczej, w której migotliwe dźwięki dają możliwość istnienia w innej formie czasu. Spektralny wymiar dźwięków opierałby się nie tyle na afektywnym, ale pasywnym odbiorze, ile na "otchłannym mis en abyme" ${ }^{\text {"10 }}$, nadającym rzeczywistości określoną strukturę, by tak rzec, nie-ontologiczną i wymuszającą na podmiotach skupienie w tej jednej chwili na autonomicznym dźwięku. Z tej perspektywy widmo dźwięków, ich pasmo i spektrum, działa jak obraz w znaczeniu wydobytym przez Nancy'ego. Jako miejsce, w którym dochodzi do kondensacji czasu, widmo oddziałuje na nas właśnie opresyjnie, nie tyle nas nawiedzając, ile bezustannie pokazując swoją nieuchronność.

Możliwa jest jednak inna wykładnia widma akustycznego, wedle której chwilowy i punktowy charakter dźwięku wchodzi w dialektyczny konflikt $\mathrm{z}$ ciszą. W tym kontekście wystarczy przypomnieć dzieła Antona Weberna, w których napięcie między izolowanym dźwiękiem i przestrzenią muzyczną wywołuje efekt szczególnej „obecności poza obecnością”, zatrzymanego w kadrze jednej chwili, która nie podlega ani trwaniu, ani rozpadowi. 
Ta „dialektyka w bezruchu”, by posłużyć się sformułowaniem Waltera Benjamina", uruchamia różne modalności czasu: teraźniejszość niejako zasysa przeszłość i jednocześnie zapowiada przyszłość. W tym jednym momencie, w którym dźwięk nas obezwładnia, rodzi się możliwość dekonstrukcji przemocy wpisanej w obraz akustyczny. W jego ścisłej strukturze nieskończonej inwersji, a więc w bezustannym ustanawianiu i niszczeniu medium, tworzy się widmo: ani obecne, ani nieobecne, obalające jednolitość dźwięku czy brzmienia, a równocześnie kierujące naszą uwagę w stronę tego, co dopiero ma się zdarzyć. Skondensowany dźwięk uruchamia więc dialektykę, w której płynność i momentalność stają się elementami widmowej gry: echo minionego brzmienia wdziera się w czas teraźniejszy, a medium, będące nośnikiem samego siebie, odtwarza się w przyszłości w swej szczątkowej formie. To jednak właśnie w tej resztkowości, wskazującej nie tyle na pozostałość po jakiejś minionej obecności, ile w owym niematerialnym śladzie, zmysłowo odczuwalnym i niedającym się przedstawić rezonansie, skrywa się spektralny charakter dźwięku.

\section{Drżenie}

Hegel bodaj jako pierwszy w nowoczesności wykazał epistemologiczną efektywność paradygmatu muzycznego i jako pierwszy tak mocno związał muzykę z doświadczeniem i podmiotowością. W Wykładach o estetyce próżno szukać strukturalnego, funkcjonalnego czy afektywnego (jak choćby u Kanta) rozumienia muzyki. Hegel traktuje ją przede wszystkim jako konkretyzację własnego zamysłu idealności sztuki, ale istotniejsze wydaje się to, że usiłując zamknąć muzykę w doświadczeniu świadomości, zarazem mimowolnie pokazuje niemożliwość własnego projektu. Już na samym początku Wykładów, w rysowanym przez filozofa podziale sztuk, pojawia się wątpliwość czy raczej aporia, która odtąd będzie stale towarzyszyła czytelnikowi podczas lektury. Wszystko zaczyna się od opracowania pewnego rodzaju fantomowej ontologii muzyki. Odróżniając malarstwo od muzyki, Hegel wydobywa, a raczej ustanawia między nimi nieprzekraczalną różnicę, która jest zarazem warunkiem możliwości pojawienia się muzyki jako znaku, który sam siebie znosi. Rzecz jasna, mamy tu do czynienia z wprowadzeniem w ruch dialektycznej maszynerii w postaci dwuznacznego pojęcia Aufhebung, a więc negacji, która zachowuje zanegowany przedmiot i zmienia jego postać, ale ważniejsza wydaje się

11 Por. W. Benjamin Pasaże, przeł. I. Kania, red. R. Tiedemann, Kraków 2005, s. 509. 
uporczywość, z jaką Hegel trwa przy kategoriach pozoru ${ }^{12}$ i złudzenia. Malarstwo, należące jeszcze do filozofii reprezentacji, wytwarza mimetyczne podobieństwa, a tym samym uruchamia niedialektyczny mechanizm analogii. Innymi słowy, przedstawienia malarskie separują podmiot od przedmiotu, stwarzając iluzję przestrzeni. Dopiero właśnie w muzyce możliwe staje się zniesienie owego widmowego elementu, który przestaje pełnić rolę podobieństwa, a przeobraża się w niezmysłowe medium brzmienia. Przestrzeń zostaje zatem zastąpiona przez czas, dzięki czemu muzyka umożliwia przemianę tego, co tkwi nieruchomo w reprezentacji, w rodzaj temporalnej osobliwości. To ona nadaje jednolity „ton” rzeczywistości, który jeszcze nie jest językiem, choć język jako taki okazuje się przedmiotem muzycznej symulacji.

Choć zatem w sensie ścisłym muzyka i malarstwo należą do subiektywnej sfery sztuki, to ich odróżnienie, jakiego dokonuje Hegel, wprowadza ciekawy wątek. Jeśli bowiem dźwięk w swym wymiarze negatywnym jest odpowiednikiem abstrakcyjnej właściwości reprezentacji, czyli widzialności, to słyszalność jako cecha muzyki stanowi tylko jeden z jej aspektów. Zasadnicze przejście od rozproszonej materii obrazu widzialnego do punktowej jedności obrazu słyszalnego odsłania puste miejsce, w którym panuje widmo. W najistotniejszym pod tym względem fragmencie Hegel powiada:

Ale punkt jako taka negatywność jest czymś konkretnym i czynnym zniesieniem przestrzeni jeszcze w obrębie materialności jako ruch i zachwianie się w sobie samym ciała materialnego w swoim stosunku do siebie samego. ${ }^{13}$

Kluczowe w tym fragmencie jest, rzecz jasna, owo enigmatyczne „zachwianie się" (co tłumacz skądinąd oddaje w przypisie w alternatywnej postaci jako „drżenie”). Hegel traktuje ten moment w swoim dyskursie lekko i przechodzi do próby opisania muzyki jako modelu idealnego doświadczenia estetycznego. Tymczasem owo „zachwianie” czy „drżenie” nie tylko pokazuje niestałość dźwiękowego modelu poznawczego, ale także wprawia w ruch jego performatywną moc, przy czym sam ten performatyw ani nie naśladuje języka, ani się nim nie posługuje, lecz wciela w siebie to, co niematerialne,

12 Na ten temat więcej: M. Pańków Hegel i pozór.Źródła i przedmiot dialektyki spekulatywnej, PWN, Warszawa 2014.

13 G.W.F. Hegel Wykłady o estetyce, przeł. J. Grabowski, A. Landman, PWN, Warszawa 1964, t. 1, S. 148. 
i wytwarza efekty akustycznej obecności, a więc ostatecznie spektralne echa. Hegel wiąże negatywność z momentem przejściowym, ale to właśnie w tym nieoznaczonym miejscu toczy się cała gra o uznanie muzyki za prawomocną i subiektywną konkretyzację formy estetycznej. Rozpad medium, o którym tak często można przeczytać w Wykładach, nie stanowi etapu w rozwoju sztuki, lecz zasadniczo podważa możliwość wyznaczenia kresu i początku muzyki, bowiem są one wpisane uprzednio w samą czasową strukturę dźwięku. Jego ulotność nie podlega substancjalizacji: muzyka, słuchanie, słyszenie nie ma w sobie żadnej istoty, wręcz przeciwnie, za sprawą odwróconego mechanizmu deiktycznego unieważnia i wymazuje samo siebie; wskazuje, ale obiekt tego wskazania pozostaje pusty. Nie jest to, rzecz jasna, negatywność, o której mówi Hegel, a więc rozumiana jako konieczność pracy pojęciowej, lecz raczej pewnego rodzaju wyrwa i nieciągłość w systemie dialektycznym, a mówiąc ściślej: niemożność przezwyciężenia sprzeczności.

O ile zatem muzyka, dla Hegla rozpięta między zachodzącymi na siebie sferami wnętrza i zewnętrza, idealności i materialności, może formalnie pełnić określoną funkcję sztuki, o tyle nie może stać się zdarzeniem. To właśnie w miejscu „rozchwiania”, prowadzącego do rozpadu muzycznego zapośredniczenia, odsłania się negatywność innego typu, pokazująca, że dźwięk nie jest zniesieniem sprzeczności, lecz ucieleśnieniem aporii rodzących się między językiem a rzeczywistością. Mówiąc inaczej, tam, gdzie Hegel chciałby - poprzez muzykę - odnaleźć pojednanie w klasycznym ideale sztuki, tam ujawnia się fundamentalne pęknięcie w samej strukturze doświadczenia. Materialna strona dźwięku rozchodzi się z jego stroną formalną, co powoduje, że brzmienie czy, szerzej: muzyka staje się zdarzeniem ${ }^{14}$. Ale też żelazna konsekwencja wpisana w Heglowski system uzmysławia ten moment niepomyślany i niedający się pomyśleć15. Czyż tym elementem, który nie stanowi ani ontologicznego braku, ani utraty języka pośredniczącego ze światem, ostatecznie nie jest samo akustyczne widmo? To właśnie w tym miejscu, krytycznym dla samej dialektyki, gdzie obecność, znak, materia ukazywane są w momencie przesilenia, pojawia się dźwięk jako ambiwalentna forma intensywności i rozproszenia, zmienności czasu i jego implozji. Czas zatem niejako gęstnieje, stając się ową „indywidualną jednością punktu”, którą tylko pozornie można opisać w kategoriach negatywnych, jako to, co jest wtórne,

14 Por. J.-L. Nancy Nieoczekiwaność zdarzenia, przeł. M. Kwietniewska, „Prinicipia” 2001 t. XXX-XXXI, s. 15-35. 
niezapośredniczone i co nie należy do sfery ducha. Wydaje się bowiem, że owa chwilowa synteza czasu daje się pomyśleć jedynie w kontekście swojego odwrócenia, a więc jako dekonstrukcja „momentu”, powodująca „rozchwianie” dialektycznego systemu ${ }^{16}$ : bezcielesna materialność ${ }^{17}$ muzyki zatrzymuje „na chwilę" proces znoszenia. Z perspektywy spekulatywnej ten moment to nic innego jak przejście do następnej fazy w rozwoju subiektywnej formy sztuki (czyli poezji), ale właśnie w nim należy upatrywać zdarzeniowej ${ }^{18}$ natury dźwięku. Spekulacja musi bowiem zastąpić zdarzenie zapośredniczeniem, które samo siebie odtwarza i - co ważniejsze - samo siebie ustanawia.

Akustyczna epistemologia, jaką można wyczytać' ${ }^{19}$ z Wykładów, pozwala dostrzec, że już u zarania nowoczesności mamy do czynienia z innym myśleniem o dźwiękach, już nie w kategoriach odpowiedniości i analogii, lecz w myśl krytycznej zasady dialektycznych napięćc ${ }^{20}$. To właśnie z nich, jak u Hegla, wyrastają konceptualizacje tego dziwnego doświadczenia granicy ${ }^{21}$, które muzyka uosabia, z nich także wyłaniają się zjawy powracających, niemożliwych do ustabilizowania, nieskrystalizowanych w postaci pojęcia melodii i brzmień. Z tej perspektywy muzyka jest widmem, ponieważ funkcjonuje niczym „Inny” ducha, pojęcia, substancji, zniesienia; jej materialność pozostaje osobliwa, a co za tym idzie nie daje się zredukować do postaci określonego pojęcia czy metafory. Czym więc jest muzyka? Stanowi uboczny efekt działania spekulatywnego systemu, którego nie sposób przewidzieć. Nieprzewidywalność z kolei uniemożliwia „założone” ustanawianie tego, co już istnieje. Znakomicie tę zasadę niestabilności dialektyki uchwycił Paul de Man, kiedy rozważał status znaku i wzniosłości w estetyce Hegla:

16 Jacques Derrida, proponując "relève" jako francuski odpowiednik "Aufhebung", doskonale zdawał sobie sprawę z innego znaczenia tego słowa („zluzowanie"), co w kontekście pokazuje dekonstrukcję jako permanentną grę z dialektyką. Por. również: J.-L. Nancy La Remarque spéculative. Un bon mot de Hegel, Galilée, Paris 1973.

17 G.W.F Hegel Wykłady o estetyce. Hegel wprowadza tam wspomnianą wyżej figurę "tonu“ jako pośredniczącego doświadczenia estetycznego: „To pierwsze wewnętrzne skupienie się i ożywienie materii tworzy materiał dla nieokreślonej jeszcze wewnętrznej głębi i życia ducha i pozwala duszy rozbrzmiewać w dźwiękach tej materii całą skalą swych doznań i namiętności".

18 Por. J. Derrida Szyb i piramida. Wprowadzenie do semiologii Hegla, przeł. J. Margański, w: tegoż Marginesy filozofii, przeł. A. Dziadek, J. Margański, P. Pieniążek, KR, Warszawa 2002, s. 125. Ś.F. Nowicki Akustyczny model podmiotowości w ujęciu Heglowskim, „Principia” 1998 nr 18-19.

Por. M.J. Siemek Hegel i różnica epistemologiczna , Nowa Krytyka” 2004 rocz. 16, s. 73-84.

Por. M. Blanchot L'expérience-limite, w: tegoż L'entretien inifni, Gallimard, Paris 1969. 
[Zewnętrzność] jako taka nie jest już znakotwórczą funkcją (a tak Hegel waloryzuje znak w Encyklopedii), lecz jest cytatem czy powtórzeniem wcześniej ustalonej semiozy. Ani też nie jest tropem, bo nie może być domknięta lub zastąpiona przez wiedzę o swej zredukowanej kondycji. Niczym jąkała czy zacięta płyta wytwarza to, co wciąż daremnie i bezsensownie powtarza. ${ }^{22}$

Korzystając z refleksji de Mana, można powiedzieć, że jeśli muzyka dla Hegla nie może zostać ustabilizowana, tzn. przezwyciężona w idealnej formie, to dzieje się tak dlatego, że nie sposób wyznaczyć jednego miejsca, w którym dźwięki (jak mówi Hegel, byty odseparowane od ducha) mogłyby na cokolwiek wskazywać - nie odnoszą się ani do rzeczywistości (negują możliwość referencji), ani do samych siebie (nie są autoteliczne). W tym sensie muzyka (można ją traktować jako paradygmat fonosfery) stanowi powtórzenie wyprzedzające różnicę i neutralizujące możliwość deiktycznego zapośredniczenia (odniesienia, będącego równocześnie relacją z zewnętrznym światem) - dźwięk jest zarazem przyczyną i efektem „jąkania się”, ,cytatem” $\mathrm{z}$ siebie samego. W tym sensie Heglowski model muzyki jako formy medium musi pozostać radykalnie negatywny, ponieważ samo dźwiękowe zapośredniczenie, ów antynomiczny czy aporetyczny „czasowy punkt” jest uwikłany w stale odnawiającą się konieczność myślenia w kategoriach teleologicznych. Odwracając deterministyczną i nihilistyczną wizję de Mana, zakładającą niemożność wyjścia z nieograniczonej semiozy ${ }^{23}$, można by powiedzieć, że to właśnie usunięcie celu jako takiego (włącznie z Kantowską "celowością bez celu" definiującą władzę sądzenia), pozwala pomyśleć muzykę jako widmo: zawierając się w jednej osobliwej chwili, stwarzając możliwość współobecności tego, co teraźniejsze i przeszłe, zapowiadając nieokreśloną przyszłość,

P. de Man Ideologia estetyczna, przeł. A. Przybysławski, słowo/obraz terytoria, Gdańsk 2000, s. 177.

Co de facto jest jedynie odwróceniem dialektyki, a nie jej krytycznym opracowaniem, jest dekonstrukcją pozbawioną krytycznego impulsu, a przez to - czysto reaktywną techniką lektury. Paul de Man zdaje się zapominać o prymacie świadomości w myśleniu Heglowskim. W tym kontekście warto przypomnieć słynne odczytanie dialektyki autorstwa Heideggera, łączące doświadczenie czasu z fenomenologią świadomości: „Tą dwuznacznością świadomość zdradza rys zasadniczy swej istoty: być już czymś, czym jednocześnie jeszcze nie jest. Bycie w sensie świadomościowym oznacza: przebywać Jeszcze-nie owego Już, tak mianowicie, że to Już uobecnia się w Jeszcze-nie". M. Heidegger Heglowskie pojęcie doświadczenia, przeł. R. Marszałek, w: Drogi lasu, J. Gierasimiuk i in., Aletheia, Warszawa 1997, s. 150. 
zwracając się ku samemu sobie, odkrywa dobroczynne napięcie między pustką i obecnością. Muzyka zatem zapowiada pewną możliwość istnienia (w melodii, dysharmonii, hałasie itd.) po to tylko, aby w tym samym ruchu ją unieważnić. Ostatecznie nie jest to wszelako ruch negatywny, przeciwnie: wydaje się, że dopiero wtedy, gdy postaramy się pomyśleć muzykę jako pewnego rodzaju niematerialny naddatek, ślad akustyczny, będący spektralnym migotaniem obecności i nieobecności, możemy ocalić zdarzenie wpisane w samo istnienie dźwięków, w tę enigmatyczną formę plastyczności świata. Akustyczne widmo to właśnie owo „drżenie”, echo rozlegających się brzmień, ich eliptyczne powtórzenie, wreszcie: forma doznawania czasu.

\section{Halucynacja}

Dla Gilles'a Deleuze'a sfera dźwiękowa pozwalała dostrzec elementarne mechanizmy rządzące wrażeniem, ciałem oraz filozofią. Podobnie jak w przypadku innych problemów podejmowanych przez autora Różnicy i powtórzenia, i w tym wypadku dźwięk, muzyczność, brzmienie wiążą się ściśle z próbą wypracowania nowych pojęć. Nie chodzi, rzecz jasna, o stworzenie gotowych kategorii, lecz o pracę systematycznego myślenia, którego jedynym medium może stać się właśnie pojęcie ${ }^{24}$. Zarówno w pracach autorskich, jak i w dziełach tworzonych wespół z Félixem Guattarim muzyka staje się jednym $\mathrm{z}$ naczelnych tematów, powracających raz po raz w formie wariacji. Jeśli więc mówić w przypadku tego autora o problemie medium dźwiękowego, to należy, rzecz jasna, pamiętać, że koncepcje Deleuze'a są odwrotnością podejścia Hegla ${ }^{25}$. Ale właśnie dlatego ciekawe wydaje się rozpoznanie figur widma nieuwikłanego w zależności substancji i świadomości, dialektycznego zapośredniczenia i spekulatywnego determinizmu.

Kluczowe dla zrozumienia praktyki analitycznej Deleuze'a pojęcie to refren. Ritornele, powracające dźwięki, odbicia, permutacje i różnicujące powtórzenia - to wszystko można znaleźć w Tysiąc plateau, książce, w której figura akustycznej repetycji zostaje całkowicie oddzielona od idealistycznego wzorca. Autorzy proponują w niej refleksję, dzięki której możliwe stałoby się odrzucenie skojarzenia fonosfery jedynie z czasem. Powtórzenie wpisane

24 Por. G. Deleuze, F. Guattari Co to jest filozofia?, przeł. P. Pieniążek, słowo/obraz terytoria, Gdańsk 2000, s. 22-42.

25 Na ten temat ciekawie pisze Slavoj Žižek w książce Organs without Bodies. On Deleuze and Consequences, Routledge, London-New York 2008. 
w refren wytwarza pewnego rodzaju miejsce, milieu, zarazem nośnik, jak i środowisko, a ściślej biorąc, terytorium, wokół którego organizują się wrażenia, gdzie można zauważyć różnice między intensywnościami, a także napięcia, rodzące się na styku języka i rzeczy. Inaczej niż w nowoczesnej narracji dialektycznej opisującej muzykę w kategoriach materialności i pojęcia czy ducha, opis refrenu zmierza ku pewnej ontologii miejsca, już nie autonomicznego i spoistego punktu w czasie, jak u Hegla, lecz dynamiki rozsunięcia, uprzestrzennienia. Wychodząc od opisu zachowań zwierząt oraz możliwych użytków, jakie czynią z niej artyści (np. ptaki w twórczości Oliviera Messiaena) ${ }^{26}$, autorzy wiążą powtórzenie z rytmem, który w odróżnieniu od „dogmatycznego" metrum pozostaje zawsze krytyczny. Oznacza to, że wpisana w refren właściwość „bycia pomiędzy” (miejscami, rodzajami ekspresji, sytuacjami itd.) odsłania nie tyle niespójność między różnymi porządkami rzeczywistości, ile momenty kryzysu i przesilenia, a nawet więcej - wyczerpania, stanu, jaki jest właściwy życiu² ${ }^{27}$ Przy czym te chwile zaburzenia rytmu same - jako takie - pozostają mu podporządkowane. Innymi słowy, rytm nie ma tu nic wspólnego ze strukturą muzyczną (harmoniczną czy nieharmoniczną), stanowi raczej przestrzeń metamorfozy, obiektów wyłaniających się z tego, co wirtualne.

To kluczowe dla Deleuze'a rozróżnienie na aktualne i wirtualne w przypadku rytmu pozwala zrozumieć, że medium jest istotne tylko wtedy, gdy uruchamia różne modalności stawania $\operatorname{się}^{28}$. Medium nie jest już nośnikiem znaczenia ani też nie pełni funkcji przedstawieniowych, lecz udostępnia przestrzeń dla zmiennych przedmiotów zanurzonych w żywiole „chaosmosu". To zgrabne określenie Guattariego i Deleuze'a, pokazujące połączenie kosmicznego porządku oraz niedającego się zidentyfikować i ostatecznie umiejscowić chaosu, niemal wprost prowadzi do problemu rytmu jako przestrzennej pulsacji. Ale rytm nie jest zwykłym akcentowaniem, zaznaczaniem pewnych zaprzeszłych, zapomnianych możliwości (ani nie odtwarza wypowiedzianych słów czy dźwięków, ani nie odwzorowuje tego, co już raz usłyszane), lecz działa niczym pewnego rodzaju improwizacja, która jest ,jednak złączeniem ze światem, zlaniem się z nim. [...] Wzdłuż ruchowych, gestycznych

26 Por. R. Bogue Deleuze on Music, Painting, and the Arts, Routledge, London-New York 2003, S. 13-32.

Por. G. Deleuze Wyczerpany, przeł. M. Kędzierski, ,Kwartalnik Artystyczny” 1996 nr 4.

28 Por. A. Badiou Deleuze. La clameur de l'Être, Hachette, Paris 1997. Badiou używa tu formuły „pieśni wirtualności". 
i dźwiękowych linii, znaczących codzienną wędrówkę dziecka wszczepiać się bądź kiełkować zaczynają «linie tropów» z właściwymi im pętlami, zawęźleniami, różnorodnymi pęknięciami, ruchami, gestami i dźwiękami" ${ }^{29}$.To właśnie dzięki tak pojętej improwizacji powtórzenie jest wychylone „w przód”, nie zależy od anamnezy czy aktualizacji elementów pominiętych w historii, lecz użycza formy wszelkiego rodzaju osobliwościom. To tu także rodzi się widmo, które należy pojmować nie jako element nawiedzenia z przeszłości czy nieoczekiwane pojawienie się tego, co zostało wyparte, ale jako szaleńczy nadmiar form. Tym samym to samo miejsce, milieu, okazuje się widmowe, to bowiem w nim zagnieżdżają się obiekty („terytorialne ready-mades”), które istnieją jedynie w połączeniach, w „szarym punkcie”, jak za Paulem Klee, powiadają autorzy, w nieuchwytnej przestrzeni, z której rozchodzą się rozmaite „linie”, wskazujące już nie możliwości, lecz konkretne praktyki, które stosujemy, obcując z obiektami. Refren to rodzaj miejsca skupiającego w sobie najrozmaitsze metamorfozy, doznania, wrażenia:

Czym jest więc tak naprawdę refren? Harmonika szklana - refren jest pryzmatem, kryształem czasoprzestrzeni. Oddziałuje na to, co go otacza, czy będzie tym dźwięk, czy światło, by wydobyć stąd rozmaite drgania, rozkłady, rzuty i przekształcenia. Refren obdarzony jest również funkcją katalityczną - nie tylko przyspiesza zmiany i reakcje w swym otoczeniu, lecz również wspiera pośrednie interakcje między elementami pozbawionymi tak zwanego naturalnego powinowactwa, tworząc w ten sposób uporządkowane masy. ${ }^{30}$

Z tej perspektywy refren, który tyleż determinuje przestrzeń, co ją deformuje, powołuje do życia byty fantomowe, uzależnione od anonimowych ruchów i sił, ustanowione jedynie na chwilę i przez tę chwilę funkcjonujące w danym środowisku. Fantomowa ontologia nie polega tu wszelako na braku czy utracie, wręcz przeciwnie: na fundamentalnej afirmacji świata (w myśl Nietzscheańskiej zasady amor fati) ${ }^{31}$, dzięki której nadmiar wpisany w refrenową repetycję wywołuje halucynacje. Kryje się za nimi swoista logika pragnienia, którą Deleuze opisywał w odniesieniu do Artauda i jego

G. Deleuze, F. Guattari Tysiąc plateau, Bęc Zmiana, Warszawa 2015, s. 379.

Tamże, s. 426-427.

Por. G. Deleuze Nietzsche i filozofia, przeł. B. Banasiak, Officyna, Łódź 2012, s. 219-224. 
schizofrenicznej praktyki mówienia czy naprawdę niesamowitych sposobów artykulacji. Twórca "teatru okrucieństwa” staje się dla autora Logiki sensu ważny właśnie dlatego, że pokazuje konsekwencje takiego użycia języka, które nie tylko odklejałoby ów język od znaczeń i przedmiotów, ale przede wszystkim powodowałoby rozkład wewnątrz niego samego, rozpad w środowisku samej mowy. Artaud uosabia skrajne podejście do języka w tym sensie, że zanegowanie zasady referencji powoduje, iż słowo na powrót wbija się w ciało, przechodząc wszelako drogę, by tak rzec, wyobcowania w samym brzmieniu: to zautonomizowane dźwięki, odpady języka, resztki zgłosek i brzmieniowe kontaminacje umożliwiają ponowne ucieleśnienie mowy.

W tej jednej chwili artykulacji, w głosie, który ma Artaudowi zastąpić pismo i literaturę, halucynacja staje się niezwykle intensywna. Słowa, które zgodnie z założeniami "teatru okrucieństwa" miałyby zostać przekształcone w mowę uobecniającą, bezpośrednią, przeobrażają się nie tyle w obłęd rozpadu systemu znaczeń, ile w autonomię brzmienia, czystej akustyczności, która nabiera cech materialnych. Ale głoski i dźwięki, które z założenia miałyby wybrzmieć na scenie teatralnej, nie są echem źródłowego sensu, nie da się ich również potraktować jako medium jakiejkolwiek treści czy pojęcia. Jak słusznie powiada Deleuze, to nie semantyka i komunikacja, lecz „język-afekt”, mowa pełna namiętności każe Artaudowi wierzyć nie tylko w to, co widzi, ale przede wszystkim w to, co słyszy. Akustyczne powidoki, jeśli można tak powiedzieć, ucieleśnione artykulacje, niezrozumiałe słowa to inne nazwy tego samego doświadczenia szaleństwa:

Każde słowo jest prawdziwie fizyczne, to znaczy: dotyczy bezpośrednio ciała. Procedura wygląda mniej więcej tak: jakieś słowo, nierzadko odsyłające do pożywienia , pojawia się drukowanymi, wielkimi literami niczym w jakimś collage'u, który je unieruchamia i zarazem odziera z sensu; ale w tym samym momencie, gdy przyszpilone słowo traci swój sens, rozpada się na drobne kawałki, na sylaby, litery, a zwłaszcza spółgłoski, które działają bezpośrednio na ciało, penetrując je i dręcząc. ${ }^{32}$

Przywołany na początku Boulez w innym tekście podjął pozornie czysto techniczną kwestię funkcji, jaką w muzyce sprawuje interwał. W pewnym momencie jednak mówi: „Interwał w sobie istnieje wyłącznie jako 
w c i e l o ny"33. Ta kapitalna definicja pokazuje główne problemy w rozmaitych teoriach, których autorzy starają się wydostać spod władzy wizualności. Materia i forma dźwięku, przynależna mu relacyjność, percepcja, wyobraźnia, niemimetyczny obraz, rytm i refren, cisza i dystans między dźwiękami, cielesność i abstrakcyjność dźwięku - wszystkie te kategorie prowadzą do jednego nieoznaczonego miejsca, w którym rozlega się już tylko pogłos, widmowy ślad brzmienia, które może jeszcze trwać albo które właśnie osiągnęło kres.

\section{Abstract}

\section{Jakub Momro}

JAGIELLONIAN UNIVERSITY (CRACOW)

The Echo and the Medium

This article is an attempt to define hauntology beyond the paradigm of visuality. Instead, Momro presents a hauntology based on the model of sound: acoustics, music, or more broadly speaking, the entire phonosphere. He begins by outlining the concept of the 'acoustic image' that emerges from his reading of Pierre Boulez and Jean-Luc Nancy, who tie together perception, the imagination and cognition by relating them to a nonmimetic sound image. Momro then presents two ways of understanding sound in modernity: in terms of dialectics (Hegel) and in terms of the event (Deleuze). In both cases the sound spectre, whether it is problematized directly or indirectly, turns out to be key to describing the experience of the modern subject.

\section{Keywords}

acoustic image, hauntology, perception-imagination, event

P. Boulez Leçons de musique..., s. 365 . 